\title{
Helix (Cornu) aspersa (O.F. Müller, 1774) (Gastropoda: Helicidae) in the Czech Republic
}

\author{
LuCIE JUŘIIČKOVÁ ${ }^{1} \&$ FiLIP KAPOUNEK ${ }^{2}$ \\ ${ }^{1}$ Department of Zoology, Faculty of Science, Charles University in Prague, Viničná 7, CZ-12844 Prague 2, Czech Republic; \\ e-mail: lucie.jurickova@seznam.cz \\ ${ }^{2}$ Biology \& Environmental Education Dept., Faculty of Education, Charles University, M. D. Rettigové 4, CZ-11639 Prague 1, \\ Czech Republic; e-mail: filip.kapounek@email.cz
}

\begin{abstract}
JuňičKovÁ J. \& KapouneK F., 2009: Helix (Cornu) aspersa (O.F. Müller, 1774) (Gastropoda: Helicidae) in the Czech Republic. - Malacologica Bohemoslovaca, 8: 53-55. Online serial at <http://mollusca.sav.sk > 18-November-2009.
\end{abstract}

The living hibernating population of non native species Helix (Cornu) aspersa was found for the first time in the Czech Republic.

Key words: Helix (Cornu) aspersa; non-native species; Czech Republic

\section{Introduction}

Helix (Cornu) aspersa (O.F. Müller, 1774) is a well known snail species, whose spreading may be due to its use as food-stuff. $H$. aspersa is the dominant species grown in snail farms in the whole Europe. The shell with 4-5 whorls is brownish characteristically interrupted by yellowish bands. The shell size is $30-35 \times 32-40 \mathrm{~mm}$. The aperture is large and characteristically oblique with a reflected white margin, the umbilicus is hidden (Fig. 1). For nomenclature problems see NORDSIECK (2006).

$H$. aspersa is native in the Mediterranean region including North Africa and probably in the Atlantic coastal regions from Portugal to the Netherlands and the British Isles. It was introduced to the Greece and Asia Minor in classical times (e.g. Kerney et al. 1983, Mienis 2007a, b).

During the last few decades $H$. aspersa was introduced round the world (PICKERING 2009). We have occurrence reports from South Africa ( SANDERSON \& Sirgel 2002), North and South America (CAPINERA 2001, SAKovich 2002), New Zealand (BARKer 1982), and also the Northern and Central parts of Europe. Historically this species was not documented from Sweden (von Proschwitz 1997) and Austria. Austrian populations have lived near Vienna for more than 30 years (REISCHÜTZ 1978, Fischer \& REISCHÜTZ 1996, Reischütz \& Reischütz 2000, Fischer \& Duda 2004). Most probably it was introduced by the trucks of a food supply and spread by means of the mowing mashines of street worker (REISCHÜTZ, pers. comm.). ČEJKA \& HORsÁK (unpubl.) found an empty shell in Slovakia (Bratislava - Lamač housing estate).

\section{The list of sites in the Czech Republic}

1 - Prague, Holešovice - near the Libeňský most bridge, $50^{\circ} 06^{\prime} 08^{\prime \prime} \mathrm{N}, 14^{\circ} 27^{\prime} 24^{\prime \prime E}, 6$ Sep 2009, L. Juřičková lgt., one ex.; 2 - Prague, the way to the Holešovice port along
Jankovcova Street, 5005'59"N, 14²7'09"E, 16 Oct 2008 , F. Kapounek lgt.; 6 Sep 2009, L. Juřičková lgt., very abundant, many young ex. (see Figs 2-4); 3 - Prague, Holešovice - the playground between Komunardů and Jankovcova Streets, 5006'01"N, 14²7'03"E, 6 Sep 2009, L. Juřičková lgt., one empty shell; 4 - Prague, Holešovice - Argentinská near gas station; 5006'00"N, 14²6'31"E, 2 Sep 2009, D. Král lgt., two living ex.; 6 Sep 2009, L. Juřičková lgt., five living ex.

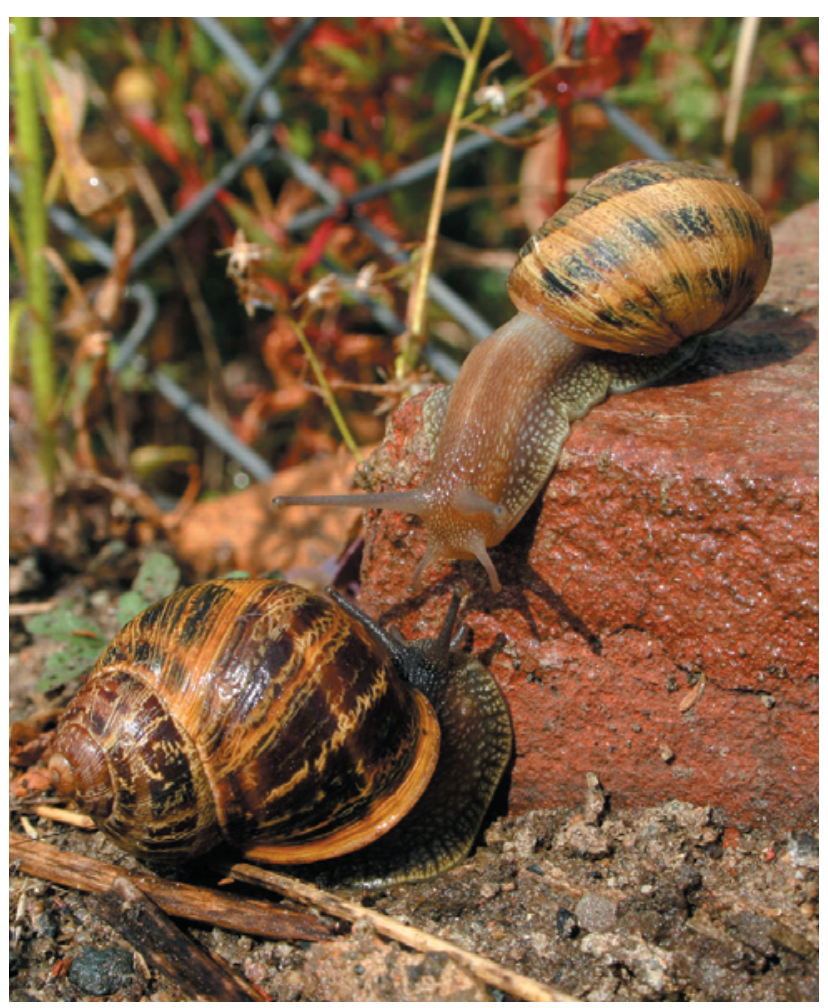

Fig. 1. Helix (Cornu) aspersa from Prague - Holešovice. 

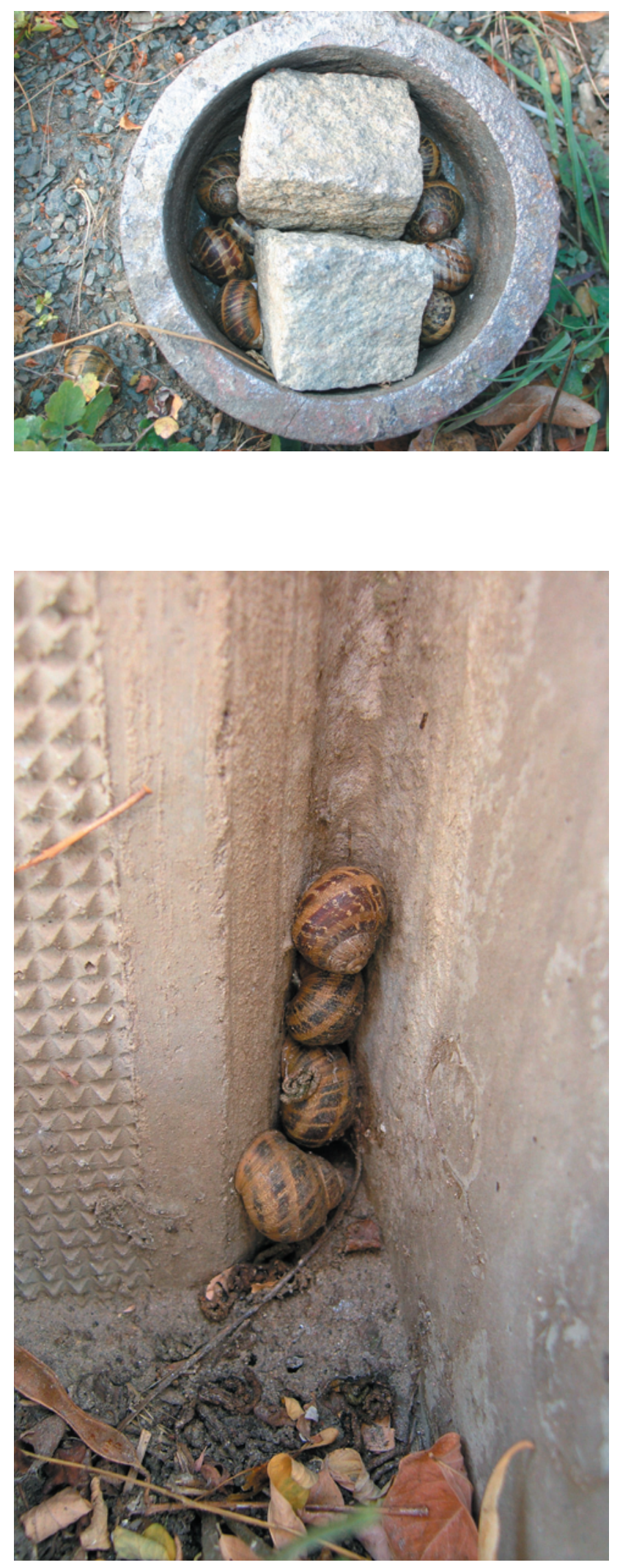

Fig. 2. (top) and Fig. 3. (bottom) Helix (Cornu) aspersa aggregations near Jankovcova Street (Prague - Holešovice).

\section{Discussion}

The worldwide spreading species Helix aspersa (O.F. Müller 1774) was not found for the first time in the Czech Republic. One empty shell was collected by J. Brabenec from Hlubočepy (Prague) fifty years ago (unpublished data), and two living specimens were collected in Mohelno (south Moravia) (Ditrich \& Kroupa 1978). However, the Prague population hibernates for the first time in the Czech Republic. The population occurs near Holešovice river port and Holešovice railway station. The possible transportation on trains or ships could be a course of its spreading. Other non-native species co-occur with $H$. aspersa in Holešovice - Arion lusitanicus (Mabille 1868), Monacha cartusiana (O.F. Müller 1774), and Cepaea nemoralis (Linnaeus 1758). Spreading of these species was monitored during last twenty years. Since the number of invasive or non-native molluscs in the Czech Republic is so far relatively small (JUŘIČKOVÁ 2006), we can expect other species in near future.

\section{Acknowledgements}

The research reported here was supported by MSMT project 0021620828 .

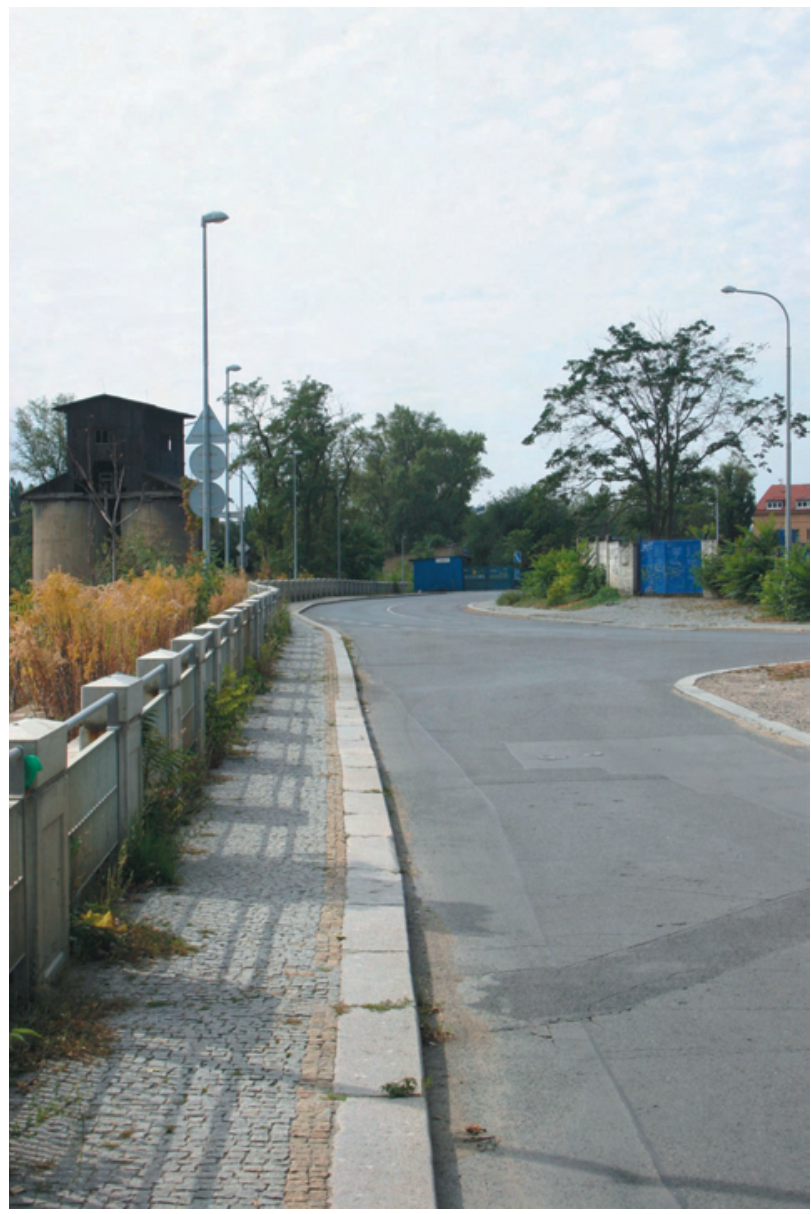

Fig. 4. Prague, the way to the Holešovice port along Jankovcova Street - the site of first and very abundant occurrence of Helix (Cornu) aspersa in the Czech Republic. 


\section{References}

CApinera J.L., 2001: Handbook of Vegetable Pests. - Academic Press, San Diego, 729 pp

BARKER G.M., 1982: Notes on the introduced terrestrial Pulmonata (Gastropoda: Mollusca) of New Zealand. - Journal of Molluscan Studies, 48: 174-181.

FisCHER W. \& DUdA M., 2004: Beiträge zur Kenntnis der Molluskenfauna Österreichs VII. Cernuella virgata (Da Costa 1778), neu für die Molluskenfauna Wiens, sowie Bemerkungen zur Ausbreitung von Monacha cantiana (Montagu 1803), Cernuella neglecta (Draparnaud 1805), Hygromia cinctella (Draparnaud 1801) und Cornu aspersum (O.F.Müller 1774) in Niederösterreich und Wien (Mollusca: Gastropoda). - Nachrichtenblatt der Ersten Vorarlberger Malakologischen Gesellschaft, 12: 10-14.

Fischer W.A. \& Reuschütz P.L., 1996: Ein Beitrag zur Kenntnis der Molluskenfauna Wiens. - Nachrichtenblatt der Ersten Vorarlberger Malakologischen Gesellschaft, 4: 49-51.

JuŘIČKovÁ L., 2006: Mollusca (Partim) - Suchozemští plži.- In: Nepůvodní druhy ve fauně a flóře České republiky, MLíkovskÝ J. \& STÝ́blo P. (eds) ČSOP, Praha, pp. 214-215.

Kerney M.P., Cameron R.A.D. \& Jungbluth J.H., 1983: Die Landschnecken Nord- und Mitteleuropas. - Verlag Paul Parey, Hamburg und Berlin, $384 \mathrm{pp}$.

Ditrich O. \& Kroupa O., 1978: Nález hlemýždě Helix aspersa Müll. v Mohelnu na Moravě [The find of snail Helix aspersa Müll. in Mohelno - Moravia]. - Památky a př́roda, 6: 379 (in Czech).

Mienis H.K., 2007a: Verslag van een onderzoek naar het voorkomen van landslakken op de Afsluitdijk uitgevoerd in 1989 [A survey of the presence of terrestrial molluscs on the Afsluitdijk, the Netherlands, carried out in 1989]. - De Kreu- kel, 43(8): 115-124 (in Dutch).

MiENIS H.K., 2007b: Een eerste poging tot inventarisatie van de landslakken in Het Burg, van Oorschotplantsoen in Ilpendam [A first attempt towards and inventory of the terrestrial gastropods in a park in Ilpendam, north-Holland, the Netherlands]. - De Kreukel, 43(3-4): 46 (in Dutch).

NoRDSIECK R., 2006: Systematics and Cornu problem. International Gastropod Society Newsletter 2. Worldwide web electronic publication. - http://www.arnobrosi.com/igs.html\#robert

Pickering J., 2009: Discover life. Worldwide web electronic publication. - http://www.discoverlife.org/mp/ 20o?kind $=$ Cornu + aspersum (the last update 14.9.2009)

Reuschütz A., 1978: Zwei eingeschleppte Schneckenarten in Wien-Simmering. - Mitteilungen der ZoologischeGeschellschaft Braunau, 3(3-4): 98.

Reischütz A. \& Reischütz P.L., 2000: Die gefleckte Weinbergschnecke Cornu aspersum (O.F. Müller, 1774) in Wien - Ottakring. - Nachrichtenblatt der Ersten Vorarlberger Malakologischen Gesellschaft, 8: 66.

SAKovich H.J., 2002: Integrated Management of Cantareus aspersus (Müller) (Helicidae) as Pest of Citrus in California. - In: Molluscs as crop pests, BARKer G.M. (ed.) CABI Publishing, CAB International UK, London, pp. 353-360.

Sanderson G. \& Sirgel W., 2002: Helicidae as Pests in Australian and South African Grapevines. - In: Molluses as crop pests, BARKer G.M. (ed.) CABI Publishing, CAB International UK, London, pp. 255-270.

von Proschwitz T., 1997: Flackig vinbergsnacka (Cornu aspersum (O.F. Müller) funnen i Sverige [The "common snail" Cornu aspersum (O.F. Müller) found in Sweden]. - Goteborgs Naturhistoriska Museum Arstryck, 1997: 23-27 (in Swedish). 